\title{
Quality of Lake Ecosystems and its Role in the Spread of Invasive Species
}

\author{
Oskars PURMALIS ${ }^{1 *}$, Laura GRĪNBERGA², Linards KḶAVIN̦Š3 ${ }^{3}$, Māris KL,AVIN̦Š ${ }^{4}$ \\ ${ }^{1,3,4}$ Department of Environmental Sciences, University of Latvia, Jelgavas str. 1, LV-1004, Riga, Latvia \\ ${ }^{2}$ Laboratory of Hydrobiology, Institute of Biology, Jelgavas str. 1, LV-1004, Riga, Latvia
}

\begin{abstract}
Lake ecosystems are important elements of hydrological regime, the quality of these ecosystems is affected by anthropogenic actions, and therefore, a variety of organisms, living in these habitats depend on the applied management solutions. Due to human activities freshwater ecosystems suffer from loss of biodiversity and increased eutrophication. Therefore, important aspects related to lake management include knowledge about the water quality, ecosystem response to climate change as well as increased risks of appearance and spreading of invasive species. Water quality, content of oxygen, nutrients, phytoplankton and distribution of macrophytes, including invasive species were analysed in Balvu and Pērkonu lakes. Presence of invasive species Canadian waterweed (Elodea canadensis) was detected, however, common reed (Phragmites australis) can be considered as expansive species. The analysis of current situation and existing management measures indicates persistent spreading of those species. Significant changes of lake water quality and climate may increase possible spreading of other, more aggressive, invasive species, for example - Nuttall's waterweed (Elodea nuttallii).
\end{abstract}

Keywords - Canadian waterweed; freshwater; invasive species; management; water quality

\section{INTRODUCTION}

In the present day the understanding of freshwater biota and its vulnerability due to climate changes has improved [1]. Climate change is expected to modify the physical characteristics of aquatic environments and intensify organic matter and energy fluxes in lakes and in their catchment area [2], [3]. This also highlights the already well-known problem of freshwaters in the World and in Europe - eutrophication, which can lead to increased productivity of water ecosystems. Climate induced changes can also lead to negative effects and changes in aquatic environments - with increase of water temperature also fundamental ecological factors, such as oxygen concentration, patterns of hydrological influences, nutrient ratio and $\mathrm{C}$ enrichment can change [4]. Temperature is also an important abiotic factor influencing macrophyte growth and production. The increased temperatures predicted in current scenarios of global climate change will directly affect shallow lake and pond macrophyte communities [5]-[7]. Moreover, climate change can also lead to increased anthropogenic constraint on freshwater ecosystems. Already observed climate change show direct influence on nutrient loadings, suspended material from catchment area [8], strong impact to water levels due to drought (significantly less amount of precipitation), and ice regime on waterbodies [9]. Availability of nutrients has positive effects on the production of plant biomass, for example,

*Corresponding author.

E-mail address: oskars.purmalis@lu.lv 
submerged and floating-leaved macrophytes can absorb nutrients both from the water and the sediments, which means that the supply of nutrients will seldom be the factor limiting growth. Emergent macrophytes absorb nutrients from the sediment and photosynthesize above the water, a strategy that makes them competitively superior to all other primary producers with respect to acquisition of nutrients and light [10]. Therefore, emergent aquatic macrophytes will become more abundant (increase by $25 \%$ ) as the reproductive capacity, including spore production, germination and sporophyte growth will be enhanced [11], [12]. Freshwater ecosystems in Europe are often habitats of invasive plants, which, similarly to native emergent aquatic macrophytes, will become more abundant due to their expansive nature. Several invasive aquatic plant species (Elodea nuttallii, Eichhornia crassipes) are listed as invasive alien species of high concern in Europe [13]. Although these species are not yet present in Latvia, due to climate change, migration of water birds and mobility of humans, the spread of these species is inevitable. Canadian waterweed (Elodea canadensis Michaux) found in Pērkonu Lake, originates from North America and has colonized Europe at least since it was first recorded in Ireland in 1836 and Britain in 1842 [14]. In 1872, it was first recorded in Latvia [15]. A description of the early invasion phase in the European part of Russia was provided by F. Herder [16], who described the spread of E. canadensis in Newa River and its tributaries since ca. 1881, blocking the mouths of the rivers, thus disrupting the natural water flow. In Latvia E. canadensis is capable to withstand large variety of substrate conditions (sandy, loamy, gravelly, muddy, and peaty). The species predominantly grows in alkaline hardwater lakes with $\mathrm{pH}$ ranging from 6 to 9.5 [17]. The adaptability to eutrophic waters is related to ability to purify water in metabolic process and accumulate both organic and inorganic nitrogen, thus the species could be used in removing nutrients from hypereutrophic waters [18], [19]. Mass occurrences of E. canadensis in Nordic countries have very probably caused disappearances of red listed plant species populations that inhabited certain lakes and ponds before the invasion of E. canadensis [20].

Climate change, pollution and disruptions in hydrological regime can also increase the spread of native species, which are expansive in nature, for example common reed $(P$. australis). Observed climate changes with increased temperature directly influences the length of the vegetative period of $P$. australis, thus the growth rate and final stem height increases [21]. In Britain, where the vegetative period is relatively short (April to September [22]) and culms grow to only $3.5 \mathrm{~m}$, hot summers can produce $0.5-1.0 \mathrm{~m}$ taller reeds than summers where cooler temperatures are observed [23], [24]. P. australis is highly productive in very high temperatures if sufficient amount of water is available to cool the leaves through transpiration [25]-[28].

Comprehensive study of two inter-connected lakes in Latvia (Balvu Lake and Pērkonu Lake), which coastline is urbanized, was conducted. Hydrochemical characterization, analysis of nutrients, biota, and macrophyte communities were analysed. In the study period (2018-2020) several substantial climate related influences, such as unusually dry summer season of 2018, and winter of 2019/2020 without stable ice regime was recorded, highlighting future climate change aspects and their impacts to lake ecosystems. In the studied lakes species with expansive nature were found $-P$. australis and invasive plant (E. canadensis). Analysis of obtained results propose options for lake ecosystem management, to prevent or mitigate climate change impacts.

\section{Methodology}

Studied lakes (Balvu lake; Pērkonu Lake) (Fig. 1) are located in NE Latvia. Lakes have Pleistocene glacial origin, they are inter-connected and outflowing rate is stabilized with non- 
regulated water locks. Between both lakes there is small extension of Lake Pērkonu where Žaugupe River and Pelnupe River carries their water, in case of Žaugupe River noticeably higher amounts of nutrients are introduced into the lake [29]. Regulation of hydrological regime of lakes has been done several times and most important effect was in the 60-ies of last century where hydrological regime of Bolupe River was changed which led to decreased water level of studied lakes by $1.5 \mathrm{~m}$. Altogether with physical changes of hydrological regime there is also increased anthropogenic pressure on lakes including release of sewage waters in lakes.

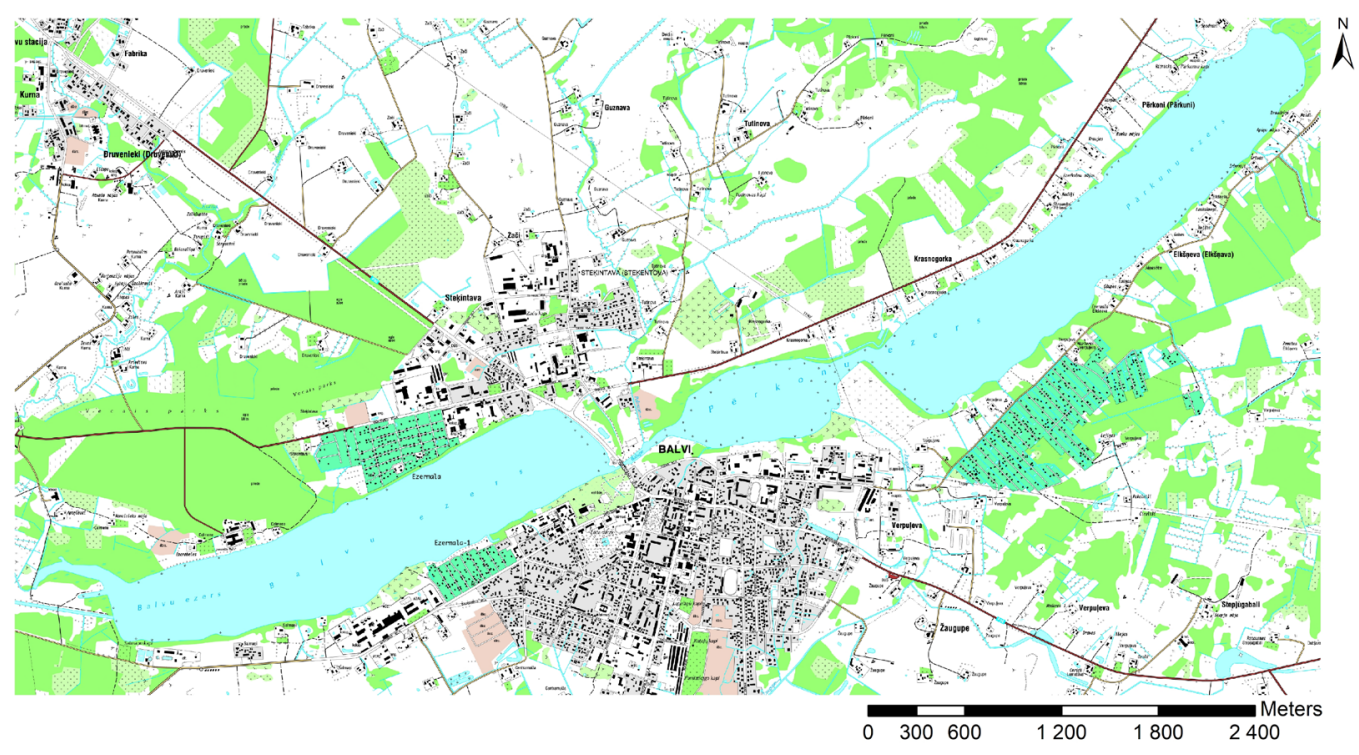

Fig. 1. Location of Balvu and Pērkonu Lakes.

Some of the physio-chemical characteristics of water including water temperature, $\mathrm{pH}$, dissolved oxygen were determined using $H A C H H Q 40$ portable multimeter. Phosphate ions, silica, total iron, color, ammonia, nitrate and nitrite were determined spectrophotometrically using a $H A C H D R 2800$. For determination of phosphate ions the ascorbic acid reduction method with persulphate digestion was used. Silica was determined by the ammonium molybdate method. Ammonia ions were determined according to phenate method [30]. Nitrates were determined using cadmium reduction method, but for nitrites diazotization method according to $H A C H$ water analysis handbook was used [31]. Sulphate ions were analyzed by turbidimetric method. Such concentrations as chloride, calcium, bicarbonate ions and total hardness were determined titrimetrically. Chemical oxygen demand (COD) was determined using oxidation with $\mathrm{K}_{2} \mathrm{Cr}_{2} \mathrm{O}_{7}$ [31].

Quantitative phytoplankton samples were fixed with $1 \%$ acidified Lugol's iodine solution. Phytoplankton counts were performed using LEICA DMI3000 inverted microscope. Individual biovolumes were calculated using appropriate geometric formulae according to their shapes and the mean dimensions of the organisms in the samples [32]. Biomass was estimated from biovolume, assuming unit specific gravity [30].

Mapping of lake macrophyte vegetation were carried out 2018-2020 in July from a boat. All aquatic macrophyte species occurring of lakes were recorded using rake sampling. Macrophyte abundance was estimated on the seven-point scale. 
Total organic carbon (TOC) and dissolved organic carbon (DOC) was measured using a Shimadzu Total Organic Carbon Analyser TOC- $-\mathrm{V}_{\mathrm{CSN}}$. DOC concentrations were measured in filtered (through a $0.45 \mu \mathrm{m}$ filter) samples.

\section{RESUltS}

Studied lakes are inter-connected with several tributaries, but major amount of water in Pērkonu Lake is received from Bolupe River (average annual flow rate $-1.17 \mathrm{~m}^{3} / \mathrm{s}$ ). Within the research period restoration (dredging) of Bolupe River has been done in several stages to prevent flooding of agricultural lands [33]. Restoration activities of Bolupe River have made impact to the water quality of Perkonu Lake increasing the number of suspended particles. The upper part of the river was dredged first and rest of river was shallow and overgrown contact zone (Fig. 2) acting like buffer zone for accumulation of suspended material and partial assimilation of nutrients. Since the restoration has been finished in 2020 , there is no buffer zone and the water flow to the lake is undisturbed carrying nutrients and organic matter in noticeably higher amounts (Table 2). In regard to expansion of invasive species freshly renovated or created waterbodies are with highest risk for invasion of E. canadensis [17]. Pērkonu Lake with area $-2.28 \mathrm{~km}^{2}$ and average depth $-1.3 \mathrm{~m}$ is connected to Balvu Lake with area $-1.68 \mathrm{~km}^{2}$ and average depth $-2.2 \mathrm{~m}$ (max. $\left.3.9 \mathrm{~m}\right)$. As described previously [29] on Balvu Lake water locks which stabilize water regime on studied lakes are installed.

Ongoing climate change and variability of climatic parameters have direct influence on aquatic ecosystems. Long-term prediction suggests increased annual precipitation up to $10 \%$ with most significant increase in winter and spring, but decrease in other seasons [34]. Increased temperature, evaporation rates and changes in distribution of precipitation may led to decreased annual runoff up to $18 \%$ [34], [35]. In the same time there is described climatic variation significantly influenced also to changes in the North Atlantic oscillation [36], [37], therefore can be expected periods with higher or lower precipitation affecting river runoff and impact to lake hydrology [38]. In period of investigating Pērkonu and Balvu Lake ecosystems and their quality several of predicted climatic events take place. In 2018 low amount of annual precipitation were observed (reaching only $360.3 \mathrm{~mm}$ ), and winter of $2019 / 2020$ was different by the lack of snow cover and even periods of positive temperatures in the usually coldest months - average monthly temperature in February reaches $+1.04{ }^{\circ} \mathrm{C}$ (Table 1) [39]. Therefore, in the winter of 2019/2020 there was no stable ice cover on the lakes and only for a short period of time patches of ice were formed. Although the period of the study is 3 years, such distinct differences in the climatic conditions provide the possibility to detect lake ecosystems response to such events indicating possible future trends of climate change impacts.

Previously characterized sediments of lakes [40] showed abundance of nutrients, mostly recognized as of allochthonous material from watershed basin, especially in Pērkonu Lake. Also, Pērkonu Lake as a first lake accumulates most of the material carried with rivers. Analysis of sediments showed that they are formed mostly from vascular plants (63$78 \%$ ) [40]. Current prediction, considering the increased river runoff forecasts, expansion of macrophytes due to the increased amount of available nutrients. Both lakes differentiate not only in considerably higher nitrogen and carbon amount in sediments of Pērkonu Lake, but also by their average depth. Therefore, in Pērkonu Lake appropriate conditions of expansion of macrophyte communities are available.

The macrophyte communities in both lakes are characterized by high abundance of emergent species, where Phragmites australis is dominating. In Pērkonu Lake total coverage 
of macrophytes exceeds $70 \%$ (including submerged macrophytes) of lake area. Wide areas of littoral are overgrown with dense stands of P. australis, in the zone of submerged macrophytes dominate Potamogeton lucens, Ceratophyllum demersum, Stratiotes aloides and E. canadensis. In Balvu Lake total coverage of macrophytes reaches $15 \%$ of lake area. Macrophyte development probably is limited by higher average depth $(2.2 \mathrm{~m})$, intensive anthropogenic activities including water transport, beaches, recreational activities, and algal blooms which compete with macrophytes for assimilation of nutrients in the summer season. Therefore, only emergent and floating-leaved species are able to grow in lake.

Regarding climate changes, in Finland about half a dozen new observations of E. canadensis discovered in 1985-2006 occurred up to a maximum of $300 \mathrm{~km}$ north from the areas predicted as climatically suitable. These new records suggest that either the species has been able to accelerate its spread towards northernmost Europe during recent years more than simulated by the bioclimatic models, or that a series of unusually warm years during the last 15 years in Finland [41], [42] and elsewhere in Europe [43] has enabled E. canadensis to make major dispersal jumps. Indeed, the northernmost records have been made quite recently, one in 1994 and the other in 2001, and thus these observations probably reflect the accumulating effect of the recent warm years [11]. Warming climate can reduce the extent of ice cover and cause warmer water temperatures in high latitude water bodies, and thus allow the further expansion of invasive aquatic species such as elodea [44], and even probability of appearing water hyacinth already found in Belgium [45].

TABLE 1. MONTHLY DATA Of TEMPERATURE AND PRECIPITATION IN 2018-2020

\begin{tabular}{lcccccc}
\hline & \multicolumn{3}{c}{ Precipitation, mm } & \multicolumn{3}{c}{ Temperature, ${ }^{\circ} \mathbf{C}$} \\
\hline Year/month & $\mathbf{2 0 1 8}$ & $\mathbf{2 0 1 9}$ & $\mathbf{2 0 2 0}$ & $\mathbf{2 0 1 8}$ & $\mathbf{2 0 1 9}$ & $\mathbf{2 0 2 0}$ \\
January & 34.6 & 29.3 & 20.3 & -2.63 & -5.84 & 1.74 \\
February & 9.5 & 28.2 & 53.1 & -8.44 & -0.26 & 1.04 \\
March & 12.4 & 33.0 & 62.8 & -3.33 & 1.59 & 2.29 \\
April & 35.1 & 0.2 & 23.4 & 7.69 & 7.90 & 5.01 \\
May & 24.3 & 65.0 & 68.1 & 15.54 & 11.86 & 9.49 \\
June & 39.8 & 62.2 & 63.4 & 15.72 & 18.55 & 18.52 \\
July & 21.2 & 91.9 & 78.3 & 19.70 & 15.49 & 16.15 \\
August & 55.6 & 50.2 & 30.6 & 18.03 & 16.14 & 16.53 \\
September & 23.7 & 61.9 & 39.0 & 14.01 & 11.09 & 13.46 \\
October & 51.2 & 52.1 & 71.2 & 6.69 & 7.37 & 8.78 \\
November & 17.0 & 62.7 & 40.3 & 1.54 & 2.77 & 3.80 \\
December & 35.9 & 58.2 & 48.8 & -2.65 & 1.50 & -0.97 \\
Annual sum, $\mathbf{m m} /$ average & & & & & & \\
temperature, ${ }^{\circ} \mathbf{C}$ & 360.3 & 594.9 & 599.3 & 6.82 & 7.35 & 7.99 \\
\hline
\end{tabular}

Differences in both of the inter-connected lakes are noticeable also by phytoplankton communities. In Balvu Lake blue-green algae (Cyanophyceae) phytoplankton dominates $(89 \%)$ and one of key factors could be availability of nutrients which support biological processes in freshwaters [46], [47]. Moreover, reduced N inputs in Balvu Lake in comparison to $\mathrm{P}$ lead to development of nitrogen-fixing cyanobacteria (Aphanizomenon flos-aquae) forming most part of phytoplankton community. Although these algae in Pērkonu Lake are in small concentrations, but in extension of lake which have direct contact to Balvu Lake amount reaches up to $30 \%$ of phytoplankton biomass while in open Pērkonu Lake $50 \%$ of 
phytoplankton consists from diatoms (Diatomophyceae). One of reasons for such differences of phytoplankton communities in both lakes can be related with prevalence of macrophytes in both lakes supported by the study of Chang X. and co-authors [48].The findings suggest that macrophyte allelopathy can suppress cyanobacteria blooms [48]. In the same time other studies [49] show increased oxidative stress in aquatic macrophyte due to cyanobacteral toxin microcystin. For example, lack of submerged plant communities in Balvu Lake compared to Pērkonu Lake can be related not only on limited growing area, but also to possible oxidative stress.

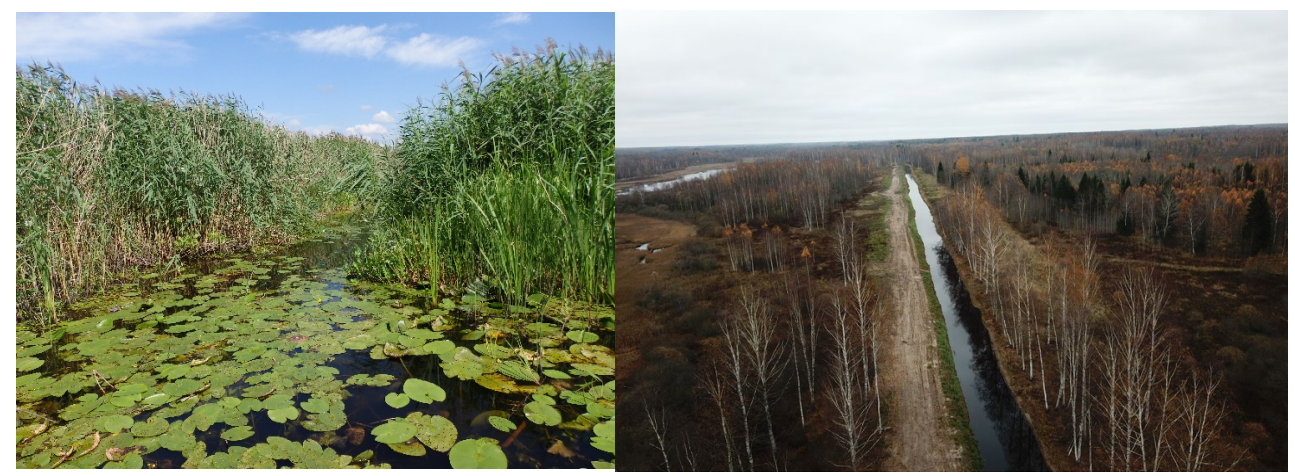

Fig. 2. Bolupe River before (left) and after restoration (right) [33] of riverbed.

Analysed hydrochemical parameters show relatively stable seasonal values and highest variability demonstrates values which characterize nutrients and parameters directly connected to biological constituents ( $\mathrm{Si}, \mathrm{Fe}$ ) and water flow (COD, Suspended material). Although major source of nutrients and suspended material in Pērkonu Lake comes from Bolupe River, slightly higher concentrations of nutrients are present in Balvu Lake (Table 2). This phenomenon shows dominant accumulation of suspended material as well as part of nutrients in Pērkonu Lake and assimilation of biogenic elements in macrophytes. In result first lake in this hydrological system is shallower with more accumulated organic material and nutrients (in sediments), and second lake is deeper, but with highly developed phytoplankton and nutrient content in water. Main reason for differences of nutrients is not only tributaries with elevated concentrations of biogenic elements and sources in coastal area, but also dominant material accumulation in Pērkonu Lake and noticeably higher occupied area with macrophytes, accordingly $-15 \%$ in Balvu Lake while up to $70 \%$ in Pērkonu Lake considering the depth of lake and colonisation depth of macrophytes. Blue-green algae can assimilate $\mathrm{N}$ from the atmosphere while in autumn period nutrients were released in water, but in Pērkonu Lake part of nutrients can be stored in roots and body of macrophytes. Existing conditions regarding expansion of invasive species in studied lakes mainly differs by their depth, available nitrogen, phosphorus, and carbon in sediments. Both are influenced by water regime regulation, however due to the more recent changes in the nutrient flow, Pērkonu Lake is more affected. Regarding climate related effects, significant decrease of the water levels of studied lakes were recorded as well as smallest tributaries were almost without water in 2018 . Lack of fresh water delivery in these lakes with their local conditions shows elevated concentrations of ammonia, affecting water quality and biota. After the period of drought decrease in the amount of nutrients was expected, however, it was higher due to possible flow of water masses rich with nutrients and organic matter from catchment area. Our findings on studied parameters in lakes and their changes due to climate and morphological changes have similar trend as previously described [50] in analysed global data set of freshwater lakes. 
Globally, any change in $\mathrm{N}, \mathrm{P}$ and $\mathrm{C}$ cycles causes changes which in result affect all three cycles [50]. Moreover, climatic parameters have significant correlation with TOC (46.2\%) [50] also describing increase of TOC concentration and slight increase of suspended material in studied lakes which only partly can be influenced by restoration of Bolupe River riverbed. Less negative temperatures and rain in winter season can increase surface runoff as well as rising annual temperature can stimulate decomposition of organic matter in soils therefore increasing TOC in aquatic ecosystems [51].

TABLE 2. QUANTIFIED PARAMETERS IN BALVU AND PĒRKONU LAKES

\begin{tabular}{lccccccc}
\hline \multicolumn{1}{c}{ Sampling time } & $\mathbf{P O}_{4}{ }^{3-}, \mathbf{m g} / \mathbf{l}$ & $\begin{array}{l}\mathbf{N O}^{-}, \\
\mathbf{m g} / \mathbf{l}\end{array}$ & $\mathbf{N O}^{-}, \mathbf{m g} / \mathbf{l}$ & $\begin{array}{l}\mathbf{N H}_{4}{ }^{+}, \\
\mathbf{m g} / \mathbf{l}\end{array}$ & $\begin{array}{l}\mathbf{T O C}, \\
\mathbf{m g} / \mathbf{l}\end{array}$ & DOC, $\mathbf{m g} / \mathbf{l}$ & $\begin{array}{l}\text { Suspended } \\
\text { particles, } \mathbf{m g} / \mathbf{l}\end{array}$ \\
\hline March 2018 & & \multicolumn{7}{c}{ Balvu Lake } \\
July 2018 & 0.040 & 3.040 & 0.036 & 0.480 & 28.57 & 28.09 & 2 \\
August 2018 & 0.061 & $<0.007$ & $<0.015$ & 0.109 & 31.94 & 30.81 & 9 \\
November 2018 & 0.010 & 5.750 & 0.020 & 1.268 & 40.77 & 35.26 & 24 \\
January 2019 & 0.135 & 0.102 & 0.025 & 0.053 & 33.27 & 32.89 & 4 \\
March 2019 & 0.015 & 3.700 & 0.017 & 0.491 & 29.95 & 28.88 & 2 \\
July 2019 & 0.010 & 8.700 & 0.050 & 1.445 & 38.13 & 31.56 & 28 \\
February 2020 & 0.058 & 0.016 & $<0.015$ & 0.081 & 29.83 & 29.02 & 8 \\
July 2020 & 0.011 & 3.300 & $<0.015$ & 0.815 & 37.11 & 36.56 & 7 \\
November 2020 & 0.055 & 0.011 & $<0.015$ & 0.087 & 32.18 & 31.43 & 8 \\
\hline & 0.077 & 1.100 & 0.015 & 0.549 & 30.67 & 30.34 & 6 \\
\hline March 2018 & & & Pērkonu Lake & & & \\
July 2018 & 0.061 & 1.965 & 0.038 & 0.150 & 30.05 & 28.94 & 6 \\
August 2018 & 0.027 & 1.030 & $<0.015$ & 0.010 & 32.45 & 31.68 & 8 \\
November 2018 & 0.007 & 5.310 & 0.023 & 1.310 & 35.27 & 33.34 & 10 \\
January 2019 & 0.037 & 0.084 & 0.025 & $<0.009$ & 36.18 & 34.87 & 3 \\
March 2019 & 0.015 & 4.200 & 0.025 & 0.900 & 31.64 & 31.01 & 5 \\
July 2019 & 0.016 & 9.050 & 0.033 & 1.250 & 41.38 & 35.11 & 32 \\
February 2020 & 0.029 & 1.190 & $<0.015$ & 0.060 & 33.52 & 32.45 & 9 \\
July 2020 & 0.011 & 3.100 & $<0.015$ & 0.960 & 38.77 & 38.26 & 10 \\
November 2020 & 0.040 & 1.320 & $<0.015$ & 0.050 & 35.49 & 34.93 & 8 \\
\hline & 0.066 & 1.520 & 0.018 & 0.610 & 43.87 & 31.83 & 5 \\
\hline
\end{tabular}

Another important aspect of climate induced effects besides water regime is the temperature and corresponding solubility of oxygen. Our data of the studied lakes shows higher temperature (up to $1.1{ }^{\circ} \mathrm{C}$ ) in winter period after hot and dry summer, especially in the deeper parts of lakes. Increased loads of nutrients in lakes are usually followed by low oxygen content in winter, when lakes are covered with ice. In case of Pērkonu Lake low content of oxygen in bottom part made even anoxic conditions which can cause $\mathrm{P}$ uptake form sediments [46]. Warm winter without ice cover shows optimal content and saturation of oxygen. Other important aspect demonstrates differences in summer season where important influencing factors are amount of fresh water (also precipitation) and algae blooming. In both of the shallow lakes water mixing occurs with low or no oxygen stratification in other seasons except winter, but regarding to temperature only in springs can be detected essential stratification. In studied lakes important differences have been noticed in oxygen saturation 
in November. Although in 2018 measurements have been taken after windy weather, but differences in oxygen saturation in comparison to November 2020 reaches up to $10 \%$. Effect of wind is noticeable in epilimnion of lakes (Fig. 3, Fig. 4), but despite identical temperature in Pērkonu Lake, oxygen saturation in water profile in 2020 is lowered by $6.8 \%$. In Balvu Lake similar scenario was recorded, however, the water temperature in 2020 is higher $\left(0.7^{\circ} \mathrm{C}\right)$ than in 2018.

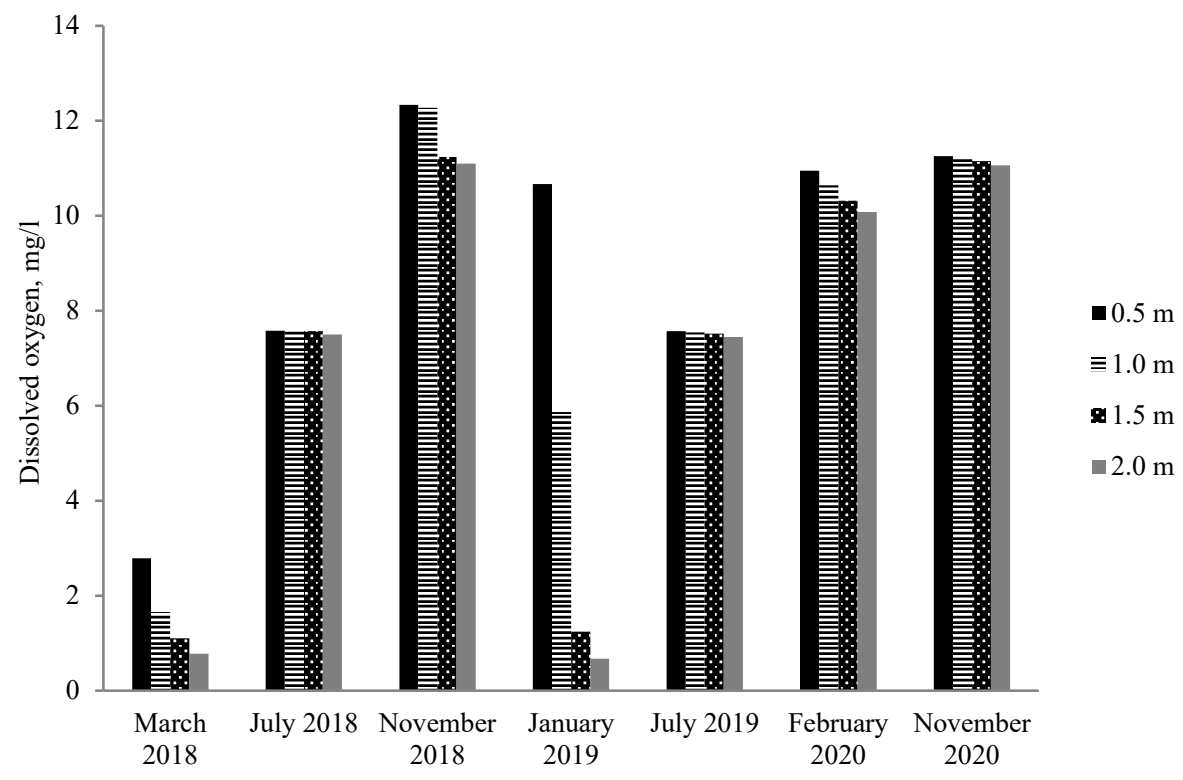

Fig. 3. Stratification of dissolved oxygen in Pērkonu Lake.

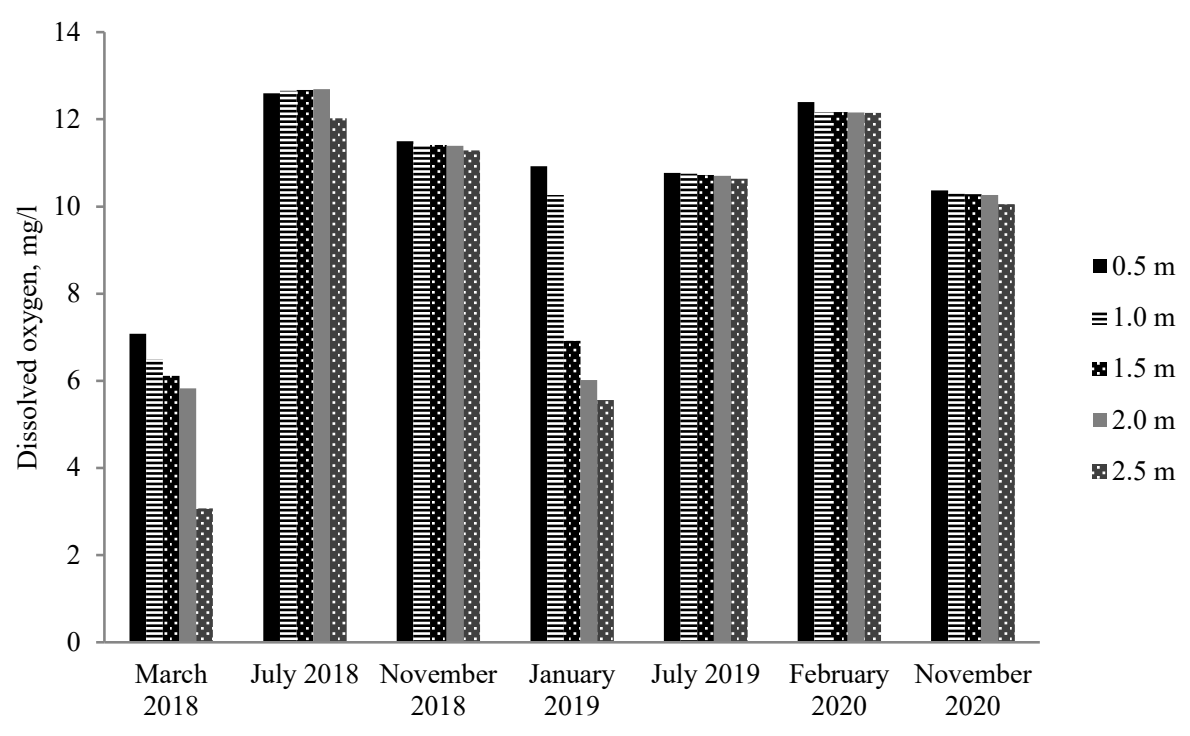

Fig. 4. Stratification of dissolved oxygen in Balvu Lake. 
Climate related effects correspond to other studies [52] in regards to increased amount of TOC and DOC in northern freshwaters [53], [54]. These factors are also related to lowered $\mathrm{O}_{2}$ concentrations [55] which directly have influence also to content of ammonia.

\section{DiscuSSION}

Analysis of impacts of climate events (lack of precipitation, warm winter and others) during the study period provides possibilities to study climate change impacts of community structure and pattern of invasive species spreading. Although both lakes are different, the sum of long-term influences leads to eutrophication of lakes and reinforced sediment accumulation. Lower average water depth of Pērkonu Lake with abundant availability of nutrients in water as well as in sediments provides conditions to expansion of macrophytes. Regarding macrophyte communities there have been detected E. canadensis and strong prevalence of $P$. australis. One of important aspect to sudden expansion of $E$. canadensis can be regulation activities of hydrological regime, respectively, forming new objects or decreasing water level. Those criteria can promote climate change with drought periods, warm winters and increased average temperature. Also produced biomass of plants supports sedimentation to even increased rates. On one hand, warm winter with availability of oxygen provides ability to oxidation reactions, but on the other hand after warm winter or several warm winters there will be plenty of material consuming oxygen when lakes will be covered with ice. These conditions will have negative effect on ecological quality of Pērkonu Lake and negative trend the quality of the lakes as well as spreading of invasive species is expected to significantly increase in Balvu Lake. In foreseeable future E. canadensis can inhabit restored Bolupe River and even reducing measures applied by intensive accumulation of material in order to prevent flooding of agricultural land if plants make dense stands. Current conditions provide advantages for other invasive macrophytes and major concerns is possible invasion of Nuttall's waterweed (E. nuttallii) [56].

Feasible options of management measures can be divided in several sections categorizing them by aims and type of influencing factors. Without the existing problems, such as eutrophication, lake ecosystems now face another challenge - the climate change [57] and spreading invasive species. In case of the studied lakes, as the most effective measures sediment removal in certain parts of Pērkonu Lake could be done, as well as formation of wetlands on tributaries. Wetlands could not only uptake nutrients, but also act as buffer in periods after drought to decrease loads of nutrients in lakes. Due to the lack of ice cover on lakes, habits of reed cutting, fishing from boats in winter as well as revised sewage system and sources of heated water in urban territory (surface runoff) should be considered or changed. Significant impact of Bolupe River to lakes raise disagreement to renovation of mentioned riverbed in straight line to prevent flooding of agricultural land. If riverbed was formed with meanders including zones with shallow water and zones with lower flowrate can decrease amount of material carried to lakes. Unlikely it does not prevent spreading of invasive species, but can shorten effective time of river as a canal to quickly drain the water to lakes.

Although both studied lakes are different despite their connection observed data can be used also in neighbouring countries in regard of management measures or for comparison of achieved data. Studied case suggests that shallow eutrophic lakes can be is higher risk category in regard to expansion of invasive species. In places where is presence of invasive species chosen management measures should avoid noticeable changes of water level or hydrological regime as well as in coastal area avoid dredging in large areas, therefore exposing fresh sediments for occupation of macrophytes (especially E. canadensis). Collected 
meteorological information in such short investigation period didn't show direct correlation with invasive species or their spreading, but indicate existing changes of climatic conditions. Moreover, such factors as decrease of water level due to lack of precipitation or warmer winters with prolonged vegetation period can increase potential of spreading invasive species, also in lakes which average depth for now limiting massive overgrowing of macrophytes. On the one hand in Pērkonu Lake several factors including climatic conditions are positive for spreading of invasive species, but on the other hand there are no comprehensive studies on macrophyte communities only from perspective of meteorological conditions, and one of reason is variability of those parameters, also in studied lakes in 3 year period studies.

\section{Conclusion}

Characteristic parameters of studied lakes have seasonal variability similarly to other water bodies in Latvia, however, increased concentrations of nutrients can be identified on an annual basis. This contributes to eutrophication processes, and current nutrient concentrations in biota in lakes are already impossible to assimilate. For now, higher average depth of Balvu Lake prevents development of invasive species, as well as decreased light penetration due to algae blooms. Pērkonu Lake with low average depth and abundance of nutrients in water and sediments create optimal conditions of macrophyte development as well as spreading of invasive species. Those circumstances created lowering of water level by $1.5 \mathrm{~m}$, anthropogenic impact, increased loads of material from watershed basin and continuing dredging of biggest tributary. Climate change even intensify existing impacts and provides aggravating spreading of invasive species.

\section{ACKNOWLEDGEMENT}

This work was supported by the European Regional Development Fund under project number 1.1.1.2/VIAA/1/16/001, Post-doctoral research project number 1.1.1.2/VIAA/4/20/723.

\section{REFERENCES}

[1] IPCC. Climate Change and Water. IPCC Technical Report VI. Geneva: IPCC, 2013.

[2] Lepane V., et al. Impact of seasonal climate change on optical and molecular properties of river water dissolved organic matter by HPLC-SEC and UV-vis spectroscopy. Chemical and Biological Technologies in Agriculture 2015:2:14. https://doi.org/10.1186/s40538-015-0040-6

[3] Baveye P. C., et al. Soil Organic Matter Research and Climate Change: Merely Re-storing Carbon Versus Restoring Soil Functions. Front. Environ. Sci. 2020:8:579904.

https://doi.org/10.3389/fenvs.2020.579904

[4] Garnier A., et al. Temporal scale dependent interactions between multiple environmental disturbances in microcosm ecosystems. Global Change Biology 2017:23(12):5237-5248. https://doi.org/10.1111/gcb.13786

[5] Mckee D., et al. Effects of simulated climate warming on macrophytes in freshwater microcosm communities. Aquatic Botany 2002:74:1:71-83. https://doi.org/10.1016/S0304-3770(02)00048-7

[6] Bhupinder D. Status of Aquatic Macrophytes in Changing Climate: A Perspective. Journal of Environmental Science and Technology 2015:8(4):139-148. https://doi.org/10.3923/jest.2015.139.148

[7] Carpenter S. R., et al. Global change and freshwater ecosystems. Annual Review of Ecology and Systematics 1992:23:119-139. https://doi.org/10.1146/annurev.es.23.110192.001003

[8] Smith V. H. Eutrophication of freshwater and coastal marine ecosystems a global problem. Environmental Science and Pollution Research 2003:10(2):126-139. https://doi.org/10.1065/espr2002.12.142 
[9] Woolway R. I., Kraemer B. M., Lenters J. D. Global lake responses to climate change. Nature Reviews Earth and Environment 2020:1:388-403. https://doi.org/10.1038/s43017-020-0067-5

[10] Brönmark C., Hansson L. A. The Biology of Lakes and Ponds. New York: Oxford University Press, 2010.

[11] Heikkinen R. K., et al. Predicting distribution patterns and recent northward range shift of an invasive aquatic plant: Elodea canadensis in Europe. BioRisk 2009:2:1-32. https://doi.org/10.3897/biorisk.2.4.

[12] Riis T., et al. Growth and morphology in relation to temperature and light availability during the establishment of three invasive aquatic plant species. Aquatic Botany 2012:102:56-64. https://doi.org/10.1016/j.aquabot.2012.05.002

[13] Regulation (EU) No 1143/2014 of the European Parliament and of the Council of 22 October 2014 on the prevention and management of the introduction and spread of invasive alien species. Official Journal of the European Union 2014:L 3174/35.

[14] Simpson D. A. A short history of the introduction and spread of Elodea canadensis Michx in the British Isles. Watsonia 1984:15:1-14.

[15] Starcs K. Kanādas elodejas 100 gadi Eiropā. Daba un Zinātne (100 years of Elodea canadensis in Europe. Nature and Science) 1937:6:193-196. (in Latvian)

[16] Herder F. Botanisches Centralblatt. Referirendes Organ für das Gesammtgebietder Botanik des In- and Ausland (Botanical central leaf. Referring body for the whole area of botany at home and abroad). 1891:12:4-5. (in German)

[17] Grīnberga L., Priede A. Elodea canadensis Michx. in Latvia. Acta Biol. Univ. Daug. 2010:10(1):43-50.

[18] Kozhova O. M., Izhnoldina L. A. Spread of Elodea canadensis in Lake Baikal. Hydrobiologia 1993:259:203-211. https://doi.org/10.1007/BF00027528

[19] Ozimek T., van Donk E., Gulati R. Growth and nutrient uptake by two species of Elodea in experimental condition and their role in nutrient accumulation in a macrophyte-dominated lake. Hydrobiologia 1993:251:13-18. https://doi.org/10.1007/BF00007159

[20] Weidema I. R. Introduced species in the Nordic countries. Århus: Nordic Council of Ministers, 2000.

[21] Haslam S. M. Phragmites Communis Trin. (Arundo Phragmites L.,? Phragmites Australis (Cav.) Trin. ex Steudel). Journal of Ecology 1972:60:585-610. https://doi.org/10.2307/2258363

[22] Haslam S. M. The Reed: A Study of Phragmites communis Trin, in Relation to Its Cultivation and Harvesting in East Anglia for the Thatching Industry. Norwich: Norfolk Reed Growers Association, 1969.

[23] Spence D. H. N. The macrophytic vegetation of freshwater lochs, swamps and associated fens. The Vegetation of Scotland. Edinburgh: Oliver \& Boyd, 1964:306-425.

[24] Haslam S. M. The Reed. Norwich: Norfolk Reed Growers Association, 2009.

[25] Pearcy R., Berry J., Bartholoomew B. Field photosynthetic performance and leaf temperatures of Phragmites communis under summer conditions in Death Valley, California. Photosynthetica 1974:8:104-108.

[26] Roberts J. Changes in Phragmites australis in south-eastern Australia: a habitat assessment. Folia Geobotanica 2000:35:353-362. https://doi.org/10.1007/BF02803548

[27] Davies R. J. P., Mackay D. A., Whalen M. A. Competitive effects of Phragmites australis on the endangered artesian spring endemic Eriocaulon carsonii. Aquatic Botany 2010:92(4):245-249. https://doi.org/10.1016/j.aquabot.2009.12.003

[28] Packer J. G., et al. Biological Flora of the British Isles: Phragmites australis. Journal of Ecology 2017:105(4):1123-1162. https://doi.org/10.1111/1365-2745.12797

[29] Purmalis O., Kḷaviņš L., Arbidans L. Ecological quality of freshwater lakes and their management applications in urban territory. Proceedings of the Research for Rural Development 2019:1:103-110. https://doi.org/10.22616/rrd.25.2019.016

[30] Rice E. W., et al. Standard methods for the examination of water and wastewater. $21^{\text {st }}$ Ed. Washington: APHA, 2005.

[31] Hach water analysis handbook. Loveland: Hach Co., 2002.

[32] Hillebrand H., Claus-Dieter D., Kirschtel D. Biovolume calculation for pelagic and benthic microalgae. Journal of Phycology 1999:35(2):403-424. https://doi.org/10.1046/j.1529-8817.1999.3520403.x

[33] ERAF 2014-2020 projects; Restoration of Bolupe water drain [Online]. [Accessed 20.01.2021]. Available: http://www.zmni.lv/eiropas-projekts/bolupes-udensnotekas-atjaunosana/ (in Latvian)

[34] Latkovska I., et al. Forecasted changes in the climate and the river runoff regime in Latvian river basins. Baltica 2015:25(2):143-152. https://doi.org/10.5200/baltica.2012.25.14 
[35] Apsīte A., et al. Climate change impacts on river runoff in Latvia. Climate Research 2011:48:57-71. https://doi.org/10.3354/cr01004

[36] Kḷaviņš M., Rodinovs V., Dravniece A. Large-scale atmospheric circulation processes as a driving force in the climatic turning ponts and regime shifts in the Baltic region. Climate change in Latvia. Riga: University of Latvia 2007:45-72.

[37] Klavins M., Rodinov V. Long-term changes of river discharge regime in Latvia. Hydrology Research 2008:39(2):133-141. https://doi.org/10.2166/nh.2008.033

[38] Grinfelde I., et al. The impact of landscape structure of catchment are on lake hydrology. SGEM 2019:19:3.1 https://doi.org/10.5593/sgem2019/3.1/S12.073

[39] Latvian Environment Geology and Meteorology (LVGMC). Data base of meteorological information. [Online]. [Accessed 02.02.2021]. Available: https://www.meteo.lv/meteorologija-datumeklesana/?nid $=461$

[40] Purmalis O., Kḷaviņš L., Arbidans L. Composition and quality of freshwater lake sediments (Balvu and Pērkonu Lakes). Environment. Technology. Resources. Proceedings of the 12th International Scientific and Practical Conference 2019:1:229-235. https://doi.org/10.17770/etr2019vol1.4129

[41] Tuomenvirta H. Reliable estimation of climatic variations in Finland. Finnish Meteorological Institute Contributions. Helsinki: Finnish Meteorological Institute, 2004:43.

[42] Pöyry J., et al. Species traits explain recent range shifts of Finnish butterflies. Global Change Biology 2009:15(3):732-743. https://doi.org/10.1111/j.1365-2486.2008.01789.x

[43] Della-Marta P. M., et al. Doubled length of western European summer heat waves since 1880. Journal of Geophysical Research 2007(D15):112. https://doi.org/10.1029/2007JD008510

[44] Rahel F. J., Olden J. D. Assessing the effects of climate change on aquatic invasive species. Conservation Biology 2008:22(3):521-533. https://doi.org/10.1111/j.1523-1739.2008.00950.x

[45] Nature platform in the Netherlands and Belgium [Online]. [Accessed 05.03.2021]. Available: https://waarnemingen.be/species/18820/statistics/

[46] Klavins M., Rodinovs V., Kokorite I. Chemistry of surface waters in Latvia. Riga: University of Latvia, 2002.

[47] Klavins M., et al. Reconstruction of Anthropogenic Impact Intensity Changes during Last 300 Years in Lake Engure Using Analysis of Sedimentary Records. Environmental and Climate Technologies 2011:7:66-71. https://doi.org/10.2478/v10145-011-0029-8

[48] Chang X., Eigemann F., Hilt S. Do macrophytes support harmful cyanobacteria? Interactions with a green alga reverse the inhibiting effects of macrophyte allelochemicals on Microcystis aeruginosa. Harmful Algae 2012:19:76-84. https://doi.org/10.1016/j.hal.2012.06.002

[49] Pflugmacher S. Promotion of oxidative stress in the aquatic macrophyte Ceratophyllum demersum during biotransformation of the cyanobacterial toxin microcystin-LR. Aquatic Toxicology 2004:70(3):169-178. https://doi.org/10.1016/j.aquatox.2004.06.010

[50] Chen M., et al. Global Landscape of Total Organic Carbon, Nitrogen and Phosphorus in Lake Water. Scientific Reports 2015:5:15043. https://doi.org/10.1038/srep15043

[51] Xu X. F., Thornton P. E., Post W. M. A global analysis of soil microbial biomass carbon, nitrogen and phosphorus in terrestrial ecosystems. Global Ecology and Biogeography 2013:22(6):737-749. https://doi.org/10.1111/geb.12029

[52] Springe G., et al. Climate change and its impacts in inland surface waters. Climate change in Latvia. Riga: University of Latvia, 2007:123-143.

[53] Kokorite I., et al. Trends of natural organic matter concentrations in river waters of Latvia. Environmental Monitoring and Assessment 2012:184(8):4999-5008. https://doi.org/10.1007/s10661-011-2315-0

[54] Dawson J. J. C., et al. Influence of hydrology and seasonality on DOC exports from three upland catchment. Biogeochemistry 2008:90:93-113. https://doi.org/10.1007/s10533-008-9234-3

[55] de Wit H. A., et al. Current Browning of Surface Waters Will Be Further Promoted by Wetter Climate Environ. Sci. Technol. Lett. 2016:3(12):430- 435. https://doi.org/10.1021/acs.estlett.6b00396

[56] Steen B., et al. Modelling hot spot areas for the invasive alien plant Elodea nuttallii in the EU. Man. Biol. Inv. 2019:10(1):151-170.

[57] Apsìte E., et al. Long-term changes in hydrological regime of the lakes in Latvia. Hydrology Research 2014:45(3):308-321. https://doi.org/10.2166/nh.2013.435 